\title{
Geology and mineralogy of Li mineralization in the Central Iberian Zone (Spain and Portugal)
}

\author{
E. Roda-Robles ${ }^{1, *}$, A. Pesquera ${ }^{1}$, P. P. Gil-Crespo ${ }^{1}$, R. Vieira $^{2,3}$, A. Lima $^{3,4}$, I. Garate-Olave ${ }^{1}$, T. Martins ${ }^{5}$ \\ AND J. TORRES-RUIZ ${ }^{6}$ \\ 1 Departamento Mineralogía y Petrología, Univ. País Vasco (UPV/EHU), Apdo. 644, 48080-Bilbao, Spain \\ 2 Sojitz Beralt Tin \& Wolfram (Portugal) S.A., Portugal \\ 3 Instituto Ciências da Terra (Pólo da UP), Porto, Portugal \\ 4 Departamento Geociências, Ambiente e Ordenamento do Território, Faculdade de Ciências, Universidade do Porto, \\ Portugal \\ 5 Manitoba Geological Survey, 360-1395 Ellice Av., Winnipeg, Manitoba R3G 3P2, Canada \\ 6 Departamento de Mineralogía y Petrología, Universidad de Granada, 18071 Granada, Spain
}

[Received 2 April 2015; Accepted 16 September 2015; Associate Editor: Kathryn Goodenough]

\section{ABSTRACT}

Lithium mineralization is common in the Central Iberian Zone and, to a lesser extent, in the Galizia-Trás-OsMontes Zone of Spain and Portugal, occurring along a 500 km-long NNW-SSE striking belt. There are different styles of Li mineralization along this belt; they are mainly associated with aplite-pegmatite bodies and, to a much lesser extent, with veins of quartz and phosphate. Lithium mineralization in the Central Iberian Zone may be classified into four types: aplite-pegmatite dykes occurring in pegmatitic fields, Li mineralization associated with leucogranitic cupolas, beryl-phosphate pegmatites and quartz-montebrasite veins. The main Li minerals of these bodies include Li-mica, spodumene and/or petalite in the pegmatitic fields and leucogranitic cupolas; triphylite-lithiophilite in the beryl-phosphate pegmatites, and amblygonite-montebrasite in the quartz-montebrasite veins. The origin of these different styles of mineralization is considered to be related to differentiation of peraluminous melts, which were generated by partial melting of metasedimentary rocks during the Variscan orogeny. On the basis of paragenesis and chemical composition, the pegmatitic fields and Li mineralization associated with granitic cupolas record the highest fractionation levels, whereas the beryl-phosphate pegmatites and quartz-montebrasite veins show lower degrees of fractionation. There are a number of textural and mineralogical indicators for $\mathrm{Li}$ exploration in the Central Iberian Zone and in the Galizia-Trás-Os-Montes Zone, with the highest economic potential for Li being in the pegmatite fields.

KeYwords: lithium, pegmatites, hydrothermal veins, granites, Variscan orogeny, Central Iberian Zone, Spain, Portugal.

\section{Introduction}

Lithium is a relatively rare element in the Earth's crust. Its uses and, consequently, its price, have increased considerably during the last decade. Among its many uses, the high demand for highefficiency Li-batteries contributes to the increasing

*E-mail: encar.roda@ehu.es

DOI: 10.1180/minmag.2016.080.049 importance of $\mathrm{Li}$ as a strategic element (Christmann et al., 2015). Lithium ( $\pm \mathrm{Sn}, \mathrm{Nb}$ and $\mathrm{Ta})$ mineralization is common in the Central Iberian Zone and, to a lesser extent, in the Galizia-Trás-Os-Montes Zone, both in the Iberian Massif of Spain and Portugal. The Li-rich rocks occur in a NNW-SSE striking belt, $\sim 500 \mathrm{~km}$ long and $\sim 150 \mathrm{~km}$ wide, being particularly abundant in the provinces of Salamanca, Cáceres, Badajoz and Pontevedra in Spain, and in the Viana do Castelo, Porto, Vila Real, Guarda, Castelo Branco and Viseu districts in 


\section{E. RODA-ROBLES ETAL.}

Portugal (Fig. 1, Table 1). The mineralization occurs principally in aplite-pegmatite bodies and, to a much lesser extent, in hydrothermal veins with quartz and phosphates. The first $\mathrm{Li}$ ore was mined in the Central Iberian Zone in Portugal, for a short period during the 1920s and 1930s (Garção, 1927), and consisted of material rich in montebrasite-amblygonite from hydrothermal veins. Subsequently, from the 1970s, lepidoliterich aplite-pegmatite dykes were exploited. More recently, petalite and spodumene-bearing pegmatites have become the main source of lithium ore in this region. Mineralization in the Portuguese part of these zones is nowadays mined intensively, and since 2009 Portugal has become the world's sixth largest producer of Li raw material (Christmann et al., 2015). With the exception of the first-mined amblygonite-montebrasite assemblage that was used for alkaline accumulators, the main application of lithium extracted in the Central Iberian Zone has been in the ceramics and glass industries.

The aplite-pegmatites exhibit varying degrees of evolution and can show distinct patterns of regional zonation. In some cases these pegmatites form a pegmatite field around a granitic body. This is the case for the Li-Sn-rich Fregeneda-Almendra pegmatite field (Salamanca-Guarda) (Roda et al., 1999; Vieira et al., 2011) and the Barroso-Alvão field (Northern Portugal) (Lima, 2000; Martins et al., 2012), among others. In other cases, $\mathrm{Li}$ enrichment is observed in the marginal and/or apical parts of leucogranites, as in the Pinilla de Fermoselle pegmatite (Zamora) (Roda-Robles et al., 2012b). Lithium enrichment can also occur in the intermediate zones of coarse-grained berylphosphate pegmatites, usually hosted by granites, such as the Cañada (Salamanca) (Roda et al., 2004) and Mangualde (Viseu) (Carvalho and Farinha, 2004) pegmatites. In addition to pegmatites sensu stricto, other Li-enriched dyke-like bodies related to granitic rocks, are also observed in the Central Iberian Zone, both in Spain and Portugal. These are very rich in quartz and amblygonite-montebrasite, and are considered as hydrothermal veins. Examples include those occurring at Valdeflores (Cáceres) (Pesquera et al., 1999), Golpejas (Salamanca) (Matín-Izard et al., 1992) and Massueime (Guarda) (Carvalho and Farinha, 2004, Roda-Robles et al., 2012c). Geological and mineralogical data indicate that all these types of $\mathrm{Li}$ mineralization belong to a metallogenetic province related to the Variscan orogeny. Field, geochemical and structural relationships, as well as the available geochronological data (Roda-Robles et al., 2009), indicate that the origin of the mineralization is most probably related to the major Variscan granitic magmatism occurring between 330 and $290 \mathrm{Ma}$.

The main Li-rich minerals occurring in the mineralization described here include the silicates spodumene, petalite, Li-rich micas, and the phosphates amblygonite-montebrasite and triphylitelithiophilite. Elbaite is only found as a minor mineral in a few pegmatites. Some, or all, of these minerals have been identified in each of these bodies, in varying modal proportions. In this paper we present a detailed petrographic and compositional description of the Li-bearing minerals in the different types of mineralization, discuss their origin, and their potential for Li-exploration.

\section{Geological setting}

Lithium-rich mineralization in the Iberian Massif is located mainly in the Central Iberian Zone and, in a lesser extent, in the Galizia-Trás-Os-Montes Zone to the north-west (Fig. 1). This zone, allocthonous to parautocthonous over the Central Iberian Zone, has been considered a subzone of the Central Iberian Zone by some authors (e.g. Julivert et al., 1972), whereas others consider it a separate zone (e.g. Farias et al., 1987; Arenas et al., 2004). In the Galicia-Trás-Os-Montes Zone, however, pegmatites only occur in materials that have similar ages and character to those occurring further south in the Central Iberian Zone. For this reason, we include both areas in this study, although it should be noted that Li mineralization is much less abundant in the Galicia-Trás-Os-Montes Zone than in the Central Iberian Zone. The Central Iberian Zone and the Galicia-Trás-Os-Montes Zone together represent the westernmost segment of the European Variscan Belt that was formed in the Upper Paleozoic during the collision of Gondwana and Laurentia (Martínez Catalán et al., 1996), with three main phases of variscan deformation (Martínez-Fernández, 1974; Noronha et al., 1981). The Central Iberian Zone is characterized by extensive granitic magmatism and by the occurrence of high-grade metamorphic complexes (Martínez et al., 1988). It is limited by the Viveiro Fault and its continuation along the Courel and Peñalba Synclinoriums to the north (Martínez Catalán, 1985), in contact with the West Asturian-Leonese Zone. The Ossa Morena Zone occurs to the south west of the Central Iberian Zone, with the Central Unit of the Badajoz-Córdoba Shear Zone separating both zones (Díez Balda et al., 1990; Azor et al., 1994). The Central Iberian 




FIG. 1. Schematic geological map of the Central Iberian Zone (CIZ) and the Galicia-Trás-Os Montes Zone (GTMZ) (Spain and Portugal) (modified from Martinez-Catalán et al., 2004, with the permission of the SGE and authors) with the location of the different Li mineralization areas. Numbers as in Table 1.

Zone is divided into two subdomains (Pérez-Estaún et al., 2004): (1) the Ollo de Sapo Domain to the north, characterized by broad outcrops of gneisses with coarse ovoid megacrystals of feldspar (augen gneisses), syntectonic granites and high-degree regional metamorphism in some areas; and, (2) the Schist-Metagreywacke Complex Domain to the south, where Neoproterozoic to Lower Palaeozoic metasedimentary rocks including metamorphosed shales, sandstones, and minor conglomerates and limestones, are intruded by abundant granitoids (Fig. 1). The central parts of the Iberian Massif are characterized by voluminous, syn- to late- $\mathrm{D}_{2}$, S-type, granitic magmatism (330-290 Ma). Recycling of meta-sediments and meta-igneous materials from the continental crust is the most plausible protolith for most of the granites in the Central Iberian Zone (Bea, 2004). The granitoids can be grouped into four categories (for an overview see Bea, 2004): (G1) early granodiorites and monzogranites; (G2) granites and leucogranites from anatectic complexes; (G3) allochthonous granites and leucogranites; and (G4) late granodiorites and monzogranites.

\section{Data collection and analyses}

Over 700 samples were collected from the different types of Li mineralization and from their country rocks. Identification of the silicates and phosphates was achieved by studying their optical properties in thin section under the polarizing microscope, powder X-ray diffraction techniques and electronmicroprobe analyses. Over 1400 microprobe analyses of micas, 120 of Li-aluminosilicates, 150 of amblygonite-montebrasite and 340 of Li-bearing Fe-Mn phosphates were obtained. Representative micas and Li-aluminosilicates were analysed at the University of Granada, using a Cameca SX50 microprobe equipped with four wavelengthdispersive spectrometers. Operating conditions were $20 \mathrm{kV}$ accelerating voltage, $20 \mathrm{nA}$ beam current and a beam diameter of $\sim 2 \mu \mathrm{m}$. Both 


\section{E. RODA-ROBLES ETAL.}

TABLE 1. Localities and main characteristics of Li mineralization in the Central Iberian Zone and in the GaliziaTrás-Os-Montes Zone.

\begin{tabular}{|c|c|c|c|c|}
\hline & Locality & $\begin{array}{l}\text { Mineralization type } \\
\text { (country rocks) }\end{array}$ & Mineral association* & Li minerals \\
\hline 1 & $\begin{array}{l}\text { Fregeneda-Almendra } \\
\text { (Salamanca, Spain- } \\
\text { Guarda, Portugal) } \\
\text { Roda et al. }(1999) \\
\text { Vieira et al. }(2011)\end{array}$ & $\begin{array}{l}\text { Several pegmatites, some Li } \\
\text { rich (micaschists) }\end{array}$ & $\begin{array}{l}\text { Qtz, Fsp, Li-Ms, Spd, Ptl, Cst, } \\
\text { Mtb }\end{array}$ & $\begin{array}{l}\text { Spodumene } \\
\text { Petalite } \\
\text { Li-Muscovite } \\
\text { Montebrasite }\end{array}$ \\
\hline 2 & $\begin{array}{l}\text { Barroso-Alvão } \\
\text { (Vila Real, Northern } \\
\text { Portugal) } \\
\text { Lima (2000) } \\
\text { Martins et al. (2012) }\end{array}$ & $\begin{array}{l}\text { Several pegmatites, some Li } \\
\text { rich (micaschists) }\end{array}$ & $\begin{array}{l}\text { Qtz, Fsp, Ms, Spd, Ptl, Cst, Nb- } \\
\text { Ta oxides }\end{array}$ & $\begin{array}{l}\text { Spodumene } \\
\text { Petalite } \\
\text { Lepidolite } \\
\text { Montebrasite }\end{array}$ \\
\hline 3 & $\begin{array}{l}\text { Tres Arroyos } \\
\text { (Badajoz, Spain) } \\
\text { Garate-Olave } \text { et al. (2014) }\end{array}$ & $\begin{array}{l}\text { Aplite-pegmatites, some Li } \\
\text { rich (metasediments) }\end{array}$ & $\begin{array}{l}\text { Qtz, Fsp, Ms, Li-Ms, Mtb, Tpz, } \\
\text { Cst, Nb-Ta oxides }\end{array}$ & $\begin{array}{l}\text { Li-Muscovite } \\
\text { Montebrasite }\end{array}$ \\
\hline 4 & $\begin{array}{l}\text { Gonçalo } \\
\text { (Belmonte-Guarda, } \\
\text { Portugal) } \\
\text { Neiva and Ramos (2010) }\end{array}$ & $\begin{array}{l}\text { Li-rich pegmatites } \\
\quad \text { (granite) }\end{array}$ & $\begin{array}{l}\text { Qtz, Fsp, Ms, Li-Ms, Amb, Ptl, } \\
\text { Tpz, Tur, Cst, Nb-Ta oxides } \\
\text { + Zwd in country rock }\end{array}$ & $\begin{array}{l}\text { Li-Muscovite } \\
\text { Amblygonite } \\
\text { Zinnwaldite }\end{array}$ \\
\hline 5 & $\begin{array}{l}\text { Segura } \\
\text { (Central Portugal) } \\
\text { Antunes et al. (2013) }\end{array}$ & $\begin{array}{l}\text { Li-rich aplite-pegmatites } \\
\text { (michaschists) }\end{array}$ & $\begin{array}{l}\text { Qtz, Fsp, Lpd, Mtb, Tpz, Cst, } \\
\text { Nb-Ta oxides }\end{array}$ & $\begin{array}{l}\text { Lepidolite } \\
\text { Montebrasite }\end{array}$ \\
\hline 6 & $\begin{array}{l}\text { Lalin-Forcarei } \\
\text { (Galicia, Spain) } \\
\text { Fuertes-Fuente and } \\
\text { Martín-Izard (1998) }\end{array}$ & $\begin{array}{l}\text { Aplite-pegmatites, some Li } \\
\text { rich (metasediments) }\end{array}$ & $\begin{array}{l}\text { Fsp, Qtz, Spd, Ms, Mtb, Cst, } \\
\text { Nb-Ta oxides }\end{array}$ & $\begin{array}{l}\text { Spodumene } \\
\text { Montebrasite }\end{array}$ \\
\hline 7 & $\begin{array}{l}\text { Queiriga } \\
\text { (Alto Vouga, Portugal) } \\
\text { Dias et al. (2013) }\end{array}$ & $\begin{array}{l}\text { Perigranitic pegmatites } \\
\text { (andalusite schists) }\end{array}$ & $\begin{array}{l}\text { Qtz, Fsp, Ptl, Lpd, Spd, Tpz, } \\
\text { Brl, Cst, Nb-Ta oxides }\end{array}$ & $\begin{array}{l}\text { Petalite, } \\
\text { Lepidolite, } \\
\text { Spodumene }\end{array}$ \\
\hline 8 & $\begin{array}{l}\text { Seixoso-Vieiros } \\
\text { (Vila Real, Northern } \\
\text { Portugal) } \\
\text { Lima et al. (2009) }\end{array}$ & $\begin{array}{l}\text { Aplite-pegmatites }+ \\
\text { leucogranitic cupola } \\
\text { (metasediments) }\end{array}$ & Qtz, Fsp, Ptl, Mtb, Spd & $\begin{array}{l}\text { Petalite } \\
\text { Montebrasite, } \\
\text { Spodumene }\end{array}$ \\
\hline 9 & $\begin{array}{l}\text { Cabeço dos Poupos } \\
\text { (Sabugal, Portugal) } \\
\text { Neiva et al. }(2011)\end{array}$ & $\begin{array}{l}\text { Li-rich aplite-pegmatites } \\
\text { (granite) }\end{array}$ & $\begin{array}{l}\text { Qtz, Fsp, Ms, Li-Ms, Zwd, Tur, } \\
\text { Cst, Nb-Ta oxides, Ap, } \\
\text { triplite }\end{array}$ & $\begin{array}{l}\text { Li-Muscovite, } \\
\text { Zinnwaldite }\end{array}$ \\
\hline 10 & $\begin{array}{l}\text { Las Navas } \\
\text { (Cáceres, Spain) } \\
\text { Gallego Garrido (1992) }\end{array}$ & $\begin{array}{l}\text { Li-rich aplite-pegmatites, } \\
\text { (metasediments) }\end{array}$ & $\begin{array}{l}\text { Qtz, Fsp, Ms, Li-Ms, Mtb, Tpz, } \\
\text { Spd, Cst, Nb-Ta oxides }\end{array}$ & $\begin{array}{l}\text { Li-Muscovite } \\
\text { Montebrasite } \\
\text { Spodumene }\end{array}$ \\
\hline 11 & $\begin{array}{l}\text { Serra de Arga } \\
\text { (Viana do Castelo, } \\
\text { Portugal) } \\
\text { Leal Gomes (1994) }\end{array}$ & $\begin{array}{l}\text { Li-rich aplite-pegmatites, } \\
\text { (metasediments) }\end{array}$ & $\begin{array}{l}\text { Qtz, Fsp, Ms, Ptl, Lpd, Spd, } \\
\text { Cst, Nb-Ta oxides }\end{array}$ & $\begin{array}{l}\text { Petalite } \\
\text { Lepidolite } \\
\text { Spodumene } \\
\text { Montebrasite }\end{array}$ \\
\hline 12 & $\begin{array}{l}\text { Puentemocha } \\
\text { (Salamanca, Spain) } \\
\text { Roda-Robles et al. } \\
(2012 a)\end{array}$ & $\begin{array}{l}\text { Beryl-phosphates subtype } \\
\text { pegmatites (granite) }\end{array}$ & $\begin{array}{l}\text { Qtz, Ms, Fsp, Bt, Brl, Fe-Mn } \\
\text { phosp, sulfides }\end{array}$ & Ferrisicklerite \\
\hline 13 & $\begin{array}{l}\text { Nossa Senhora da Assunção } \\
\text { (Alto Vouga, Portugal) } \\
\text { Dias et al. (2013) }\end{array}$ & $\begin{array}{l}\text { Beryl-phosphates subtype } \\
\text { pegmatites (granite) }\end{array}$ & $\begin{array}{l}\text { Qtz, Fsp, Ms, Brl, Bt, Fe-Mn } \\
\text { phosp, Al-phosp, Nb-Ta } \\
\text { oxides, sulfides }\end{array}$ & Triphylite \\
\hline 14 & $\begin{array}{l}\text { Pedra da Moura } \\
\text { (Ponte da Barca, Portugal) } \\
\text { Leal Gomes et al. (2009) }\end{array}$ & $\begin{array}{l}\text { Beryl-phosphates subtype } \\
\text { pegmatites (granite) }\end{array}$ & $\begin{array}{l}\text { Qtz, Ms, Fsp, Brl, Fe-Mn } \\
\text { phosp, sulfides }\end{array}$ & Triphylite \\
\hline
\end{tabular}


TABLE 1. (contd.)

\begin{tabular}{|c|c|c|c|c|}
\hline & Locality & $\begin{array}{l}\text { Mineralization type } \\
\text { (country rocks) }\end{array}$ & Mineral association* & Li minerals \\
\hline 15 & $\begin{array}{l}\text { Cañada } \\
\text { (Salamanca, Spain) } \\
\text { Roda et al. (2004) }\end{array}$ & $\begin{array}{l}\text { Beryl-phosphates subtype } \\
\text { pegmatite (gabbro and } \\
\text { granite) }\end{array}$ & $\begin{array}{l}\text { Qtz, Ms, Fsp, Tur, Bt, Grt, Brl, } \\
\text { Fe-Mn phosp, Nb-Ta oxides, } \\
\text { sulfides }\end{array}$ & $\begin{array}{l}\text { Triphylite } \\
\text { Ferrisicklerite }\end{array}$ \\
\hline 16 & $\begin{array}{l}\text { Mangualde } \\
\text { (Viseu, Portugal) } \\
\text { Carvalho and Farinha } \\
\text { (2004) }\end{array}$ & $\begin{array}{l}\text { Beryl-phosphates subtype } \\
\text { pegmatites (granite) }\end{array}$ & $\begin{array}{l}\text { Qtz, Fsp, Ms, Brl, Bt, Grt, Tur, } \\
\text { Fe-Mn phosp, Nb-Ta oxides, } \\
\text { sulfides }\end{array}$ & $\begin{array}{l}\text { Triphylite } \\
\text { Ferrisicklerite }\end{array}$ \\
\hline 17 & $\begin{array}{l}\text { Seixeira-Fonte da Cal } \\
\quad \text { (Guarda, Portugal) } \\
\text { Roda-Robles et al. (2008) }\end{array}$ & $\begin{array}{l}\text { Beryl-phosphates subtype } \\
\text { pegmatites (granite) }\end{array}$ & Qtz, Fsp, Ms, Brl, Fe-Mn phosp & Ferrisicklerite \\
\hline 18 & $\begin{array}{l}\text { Pinilla de Fermoselle } \\
\text { (Zamora, Spain) } \\
\text { Roda-Robles } \text { et al. } \\
(2012 b)\end{array}$ & $\begin{array}{l}\text { Pegmatitic cupola over a } \\
\text { granite, Li rich in its } \\
\text { upper part }\end{array}$ & $\begin{array}{l}\text { Qtz, Ms, Fsp, Tur, Lpd, Bt, } \\
\text { Zwd, Fe-Mn phosp }\end{array}$ & $\begin{array}{l}\text { Lepidolite } \\
\text { Ferrisicklerite } \\
\text { Elbaite } \\
\text { Zinnwaldite }\end{array}$ \\
\hline 19 & $\begin{array}{l}\text { Argemela } \\
\text { (Guarda, Portugal) } \\
\text { Charoy and Noronha } \\
\text { (1996) }\end{array}$ & $\begin{array}{l}\text { Microgranite + quartz- } \\
\text { albite-dykes with } \\
\text { montebrasite }\end{array}$ & $\begin{array}{l}\text { Qtz, Fsp, Ms, Lpd, Mtb, Cst, } \\
\text { Nb-Ta oxides }\end{array}$ & $\begin{array}{l}\text { Lepidolite } \\
\text { Montebrasite }\end{array}$ \\
\hline 20 & $\begin{array}{l}\text { Castillejo de Dos Casas } \\
\text { (Salamanca, Spain) } \\
\text { Martín-Izard et al. (1992); } \\
\text { Roda-Robles et al. (2013) }\end{array}$ & $\begin{array}{l}\text { Stockscheider over a } \\
\text { leucogranitic cupola in } \\
\text { contact to the micaschists }\end{array}$ & $\begin{array}{l}\text { Qtz, Fsp, Li-Ms, Ptl, Cst, Mtb, } \\
\text { Tpz, Fe-Mn phosp }\end{array}$ & $\begin{array}{l}\text { Li-Muscovite } \\
\text { Petalite } \\
\text { Montebrasite } \\
\text { Lithiophilite }\end{array}$ \\
\hline 21 & $\begin{array}{l}\text { Golpejas } \\
\quad \text { (Salamanca, Spain) } \\
\quad \text { Martín-Izard et al. (1992) }\end{array}$ & $\begin{array}{l}\text { Leucogranitic cupola }+ \\
\text { quartz dykes with } \\
\text { montebrasite }\end{array}$ & $\begin{array}{l}\text { Qtz, Fsp, Mtb, Cst, Nb-Ta } \\
\text { oxides, Tpz }\end{array}$ & Montebrasite \\
\hline 22 & $\begin{array}{l}\text { Valdeflores } \\
\text { (Cáceres, Spain) } \\
\text { Pesquera et al. (1999) }\end{array}$ & $\begin{array}{l}\text { Quartz dykes with } \\
\text { montebrasite } \\
\text { (micaschists) }\end{array}$ & $\begin{array}{l}\text { Qtz, Mtb, Cst }+ \text { Zwd, Lpd, Li- } \\
\text { Ms in country rock }\end{array}$ & $\begin{array}{l}\text { Montebrasite } \\
\text { Zinnwaldite } \\
\text { Lepidolite }\end{array}$ \\
\hline 23 & $\begin{array}{l}\text { Massueime } \\
\text { (Guarda, Portugal) } \\
\text { Carvalho and Farinha } \\
\text { (2004); Roda-Robles et al. } \\
\text { (2012c) }\end{array}$ & $\begin{array}{l}\text { Quartz dykes with } \\
\text { montebrasite }\end{array}$ & Qtz, Mtb, Cst, sulfides & Montebrasite \\
\hline 24 & $\begin{array}{l}\text { Barquilla } \\
\quad \text { (Salamanca, Spain) } \\
\quad \text { Martín-Izard et al. (1992) }\end{array}$ & $\begin{array}{l}\text { Quartz dykes with } \\
\text { montebrasite } \\
\text { (metasediments) }\end{array}$ & $\begin{array}{l}\text { Qtz, Fsp, Mtb, Cst, Nb-Ta } \\
\text { oxides, sulfides }\end{array}$ & Montebrasite \\
\hline 25 & $\begin{array}{l}\text { El Trasquilón } \\
\text { (Cáceres, Spain) } \\
\text { Gallego Garrido (1992) }\end{array}$ & $\begin{array}{l}\text { Quartz dykes with } \\
\text { montebrasite } \\
\text { (granitic cupola) }\end{array}$ & $\begin{array}{l}\text { Qtz, Fsp, Mtb, Cst, Nb-Ta } \\
\text { oxides, sulfides }\end{array}$ & Montebrasite \\
\hline
\end{tabular}

*Abbreviations: Qtz - quartz; Fsp - feldspar; Brl - beryl; Lpd - lepidolite; Spd - spodumene; Ptl - petalite; Cst cassiterite; Mtb - montebrasite; Amb - amblygonite; Ms - muscovite; Lpd - lepidolite; Tur - tourmaline; Tpz - Topaz; phosp - phosphates; Ap - Apatite; Grt - garnet, Zwd - zinnwaldite.

** The most abundant Li phases are presented in bold.

natural and synthetic standards were used: fluorite (F); sanidine (K); pollucite (Cs); synthetic $\mathrm{MnTiO}_{3}$ (Ti, Mn); diopside (Ca); synthetic $\mathrm{BaSO}_{4}(\mathrm{Ba})$; synthetic $\mathrm{Fe}_{2} \mathrm{O}_{3}(\mathrm{Fe})$; albite $(\mathrm{Na})$; periclase $(\mathrm{Mg})$; synthetic $\mathrm{SiO}_{2}(\mathrm{Si})$; apatite $(\mathrm{P})$; sphalerite $(\mathrm{Zn})$; synthetic $\mathrm{Cr}_{2} \mathrm{O}_{3}(\mathrm{Cr})$; and synthetic $\mathrm{Al}_{2} \mathrm{O}_{3}(\mathrm{Al})$. Data were corrected for ZAF values using the procedure of Pouchou and Pichoir (1985). Analytical errors are estimated to be on the order of $\pm 1-2 \%$ for major elements and $\pm 10 \%$ for minor elements. The $\mathrm{Li}$ aluminophosphates and $\mathrm{Li}-\mathrm{Fe}-\mathrm{Mn}$ phosphates were analysed at the Université Paul Sabatier (Toulouse, 
France), with a Cameca SX50 electron microprobe. For the phosphates, the operating conditions were: voltage of $15 \mathrm{kV}$ and a beam current of $10 \mathrm{nA}$ for all elements. The standards used for phosphate analyses are: graftonite for $\mathrm{P}$, corundum for $\mathrm{Al}$, hematite for $\mathrm{Fe}$, pyrophanite for $\mathrm{Mn}$, periclase for $\mathrm{Mg}$, wollastonite for $\mathrm{Ca}$ and $\mathrm{Si}$, sanidine for $\mathrm{K}$, albite for $\mathrm{Na}$, celestine for $\mathrm{S}$, baryte for $\mathrm{Ba}$ and $\mathrm{Pb}_{2} \mathrm{P}_{2} \mathrm{O}_{7}$ for $\mathrm{Pb}$.

The Li content of micas was calculated using different equations based on the positive correlation between Li and F (e.g. Tischendorf et al., 2004, Pesquera et al., 1999; Vieira et al., 2011; RodaRobles et al., 2006). For other minerals, Li was calculated assuming the ideal content in the structural formulae (for more detail, see Tables 3 to 6).

\section{General geology of the Li mineralization}

Lithium mineralization in the Central Iberian Zone is associated mainly with pegmatites, but also with leucogranitic cupolas and quartz-rich hydrothermal veins. Pegmatites are igneous rocks commonly characterized by their coarse, sometimes giant grain size, and commonly by an internal zoning with the development of a massive quartz core, intermediate zone(s) and a wall zone, in the simplest case. Pegmatitic bodies showing these features are common in the Central Iberian Zone, as for example the Puentemocha pegmatite (Salamanca, Spain) (Roda-Robles et al., 2012a) or the Nossa Senhora da Assunção pegmatite (Viseu, Portugal) (Roda-Robles et al., 2014). These are Be-P-rich pegmatites, belonging to the beryl-phosphate subtype of the Črný and Ercit classification (2005). However, in the Central Iberian Zone the pegmatite bodies that are most enriched in $\mathrm{Li}$ are texturally and compositionally quite different from the more commonly-observed pegmatites. Many of these Li-rich bodies exhibit an aplitic texture, commonly with the development of units with mineralogical layering (line-rock). Coarse crystals are also common, but usually smaller than $10 \mathrm{~cm}$ long; and the pegmatites are typically unzoned. However, these bodies are typically notably enriched in $\mathrm{Li}$, with local concentrations exceeding 2 wt. $\% \mathrm{Li}_{2} \mathrm{O}$. The different types of Li-rich mineralization from the Central Iberian Zone and the Galicia-Trás-Os Montes Zone are discussed in detail below (Table 1, Fig. 1).

\section{Lithium mineralization in pegmatite fields}

This is the most common type of Li mineralization found in the studied region. Lithium-bearing pegmatites crop out in groups of up to a few hundred dykes, hosted in granites and in metasedimentary rocks. These pegmatite dykes are of variable thickness (from a few centimetres up to $30 \mathrm{~m}$ ), and range from a few metres up to a couple of kilometres long. Their dip is very variable, from sub-horizontal (e.g. Gonçalo and Tres Arroyos fields) to sub-vertical (e.g. Fregeneda-Almendra field). Not all pegmatites in each field are enriched in Li. In some cases the pegmatite fields display a regional zoning, with barren, intermediate and Li-rich pegmatites occurring in different areas of the field, with an enrichment in rare metals mainly including $\mathrm{Li}$ and $\mathrm{F}$, but also $\mathrm{Sn}, \mathrm{P}, \mathrm{Nb}, \mathrm{Ta}, \mathrm{Rb}$ and $\mathrm{Cs}$ in some cases, as the distance to the parental granite increases (e.g. Fregeneda-Almendra and Tres Arroyos fields). Usually these Li-rich pegmatites lack internal zoning. The grain size may be very homogeneous (aplitic in some bodies and pegmatitic in others), with crystals only exceptionally $>10 \mathrm{~cm}$ long; or moderately heterogeneous, with aplitic and pegmatitic facies occurring in the same pegmatite body, without an aparent pattern for the grain size variation inside these bodies. Layering is relatively common in the pegmatites, typically parallel to the contacts with the host rocks. In such cases, the layering is developed throughout the pegmatite (e.g. Fregeneda-Almendra, Gonçalo and Tres Arroyos fields). In the simplest example, the layering consists of two mineral associations (e.g. Li-mica + quartz alternating with albite + quartz, as observed in the Gonçalo and Fregeneda-Almendra fields) (Fig. 2a); in other cases there are several different layers forming complex patterns across the dyke. Wedge-shaped crystals of K-feldspar or plagioclase that grew perpendicular to the contacts with the host-rock are common.

The mineralogy of the pegmatites is quite simple, including quartz, albite, K-feldspar and muscovite in the barren dykes; and these minerals together with spodumene, petalite, Li-muscovite and/or lepidolite, in variable proportions, in the Li-rich dykes. Those showing the highest fractionation levels are rich in Li-micas, with up to $35 \%$ mica in modal proportions. Amblygonite-montebrasite, cassiterite and $\mathrm{Nb}$ - $\mathrm{Ta}$ oxides are the commonest accessory minerals in all the dykes of the pegmatite fields.

\section{Beryl-phosphate pegmatites}

The beryl-phosphate pegmatites are not usually part of pegmatite fields in the Central Iberian Zone, and belong to the beryl-phosphate subtype defined in 
the classification of Černý \& Ercit (2005). In these pegmatites, $\mathrm{Li}$ is mainly contained in $\mathrm{Fe}-\mathrm{Mn}$ phosphates, usually of the triphylite-lithiophilite series (e.g. Cañada, Pedra da Moura, Nossa Senhora da Assunção). The phosphate masses are sub-rounded and up to $1.5 \mathrm{~m}$ in diameter, typically occurring in the intermediate zone of pegmatites that show a well-developed internal structure and a coarse grain size. The major minerals in the pegmatites include quartz, K-feldspar, plagioclase, beryl, muscovite, biotite, with schorl, $\mathrm{Nb}$-Ta oxides and apatite as minor or accessory phases. The shape of the beryl-phosphate bodies varies from tabular to turnip-shaped, and they are typically hosted by anatectic granitic plutons, frequently with a gradual contact with the host rock.

\section{Lithium mineralization associated with leucogranitic cupolas}

This paragenesis is not as common as the pegmatites described above. This type of $\mathrm{Li}$ mineralization occurs in the apical or marginal areas of highlyfractionated leucogranites, hosted by metasedimentary rocks of the Schist-Metagreywacke Complex. The associated leucogranites are typically fine grained and enriched in B, Li and F (Martín-Izard et al., 1992, Roda-Robles et al., 2012b, 2015). The apical/marginal zones are quite heterogeneous and include a range of mineral associations. The most common association consists of a fine-grained matrix of quartz, albite and Li-mica surrounding coarser crystals of K-feldspar that grew perpendicularly to the contacts with the host-rock. Accessory minerals in this association include topaz, montebrasite, petalite, cassiterite and columbite-tantalitegroup minerals. A second typical facies includes fine- to medium-sized layered, sub-horizontal textures (stockscheider), with lepidolite-rich bands alternating rhythmically with feldspar-rich bands (e.g. Castillejo de Dos Casas) (Fig. 2b). The two facies may occur in the same intrusion (RodaRobles et al., 2015). Usually the contact between the granitic and the pegmatitic rocks is gradual, being difficult to establish the limit between both lithologies (Roda-Robles et al. 2012b, 2015).

\section{Quartz-montebrasite veins}

Lithium is locally enriched in quartz-rich hydrothermal veins that occur in association with leucogranitic bodies in the central parts of the Central Iberian Zone (e.g. Golpejas, Valdeflores,
Barquilla, Massueime). The veins typically occur as thin $(<1 \mathrm{~m}$ thick) subvertical dyke-like bodies, hosted in fractures inside the granites and the metasedimentary rocks of the Schist-Metagreywacke Complex. The main Li-rich minerals in these veins belong to the montebrasite-amblygonite series, corresponding to the $\mathrm{OH}$-rich member montebrasite. Feldspars and cassiterite are commonly present in these dykes, and $\mathrm{Nb}-\mathrm{Ta}$ oxides plus other oxides and sulfides may be present locally, usually as accessory minerals.

\section{Mineral composition and textures}

The major Li-bearing minerals in the various styles of Li mineralization of the Central Iberian Zone and the Galizia-Trás-Os-Montes Zone include Li-micas, spodumene, petalite and phosphates of the triphylite-lithiophilite and amblygonitemontebrasite series. Elbaite, where present, mostly occurs as an accessory mineral. Table 2 lists the different major Li-bearing minerals in the different types of mineralization, their ideal structural formulae, Li contents of these mineral phases and general abundance in the different mineralization styles. Overall, Li-mica is the most common $\mathrm{Li}$ phase in the mineralization discussed here. Spodumene and petalite are particularly abundant in some of the dykes in the pegmatitic fields, whereas montebrasite is most commonly found in the hydrothermal veins. The main textural and geochemical features of these minerals are described below.

\section{Li-mica}

Most of the Li-micas studied belong to the muscovite-lepidolite series, although zinnwaldite is found in a few pegmatite bodies (Tables 1 and 2). In addition, abundant zinnwaldite, sometimes together with Li-muscovite and/or lepidolite, is found in the metasomatized mica-schists or granites hosting some of the mineralized zones (e.g. Valdeflores, Gonçalo).

In the pegmatite fields of the Central Iberian Zone and of the Galizia-Trás-Os-Montes Zone, Limica is usually restricted to the most fractionated bodies (i.e. the most enriched in incompatible elements), especially enriched not only in Li but also in F. These bodies are typically characterized by contact-parallel layering, consisting of a sequence in which Li-mica + quartz-rich layers alternate with albite $+\mathrm{K}$-feldspar-rich bands (Fig. 2a). In handspecimen, the Li-mica exhibits a typical lilac colour, and occurs as prismatic or wedge-shaped crystals 


\section{E. RODA-ROBLES ETAL.}


FIG. 2. (a) Rythmic layering with alternating lepidolite-rich and albite-rich bands in a aplite-pegmatite dyke from the Gonçalo field; $(b)$ similar texture as $(a)$ in the lower part, plus some wedge-shaped crystals of K-feldspar in the upper part, from the stockscheider of Castillejo de Dos Casas; (c) pinkish primary Li-mica flakes together with greyish K-feldspar crystals and quartz from the Fregeneda-Almendra field; $(d)$ cone-shaped crystals of spodumene randomly distributed together with albite crystals, within a pegmatite dyke from the Fregeneda-Almendra field; $(e)$ hand sample of weathered montebrasite (white), replaced by turquoise from Valdeflores; and $(f)$ massive triphylite crossed by a vein filled by secondary phosphate phases, from the Cañada open pit.

$(<2 \mathrm{~cm}) \quad$ (Fig. $2 c)$ (e.g. Fregeneda-Almendra, Gonçalo, Tres Arroyos, Las Navas). On the basis of these textural features and its relationship to other minerals, mica is considered a primary phase. Limica may also form irregular, fine-grained, saccharoidal aggregates with quartz and feldspar, commonly cross-cutting the primary layering of the pegmatites. Mica showing these textures is considered to be a replacement product that originated during an episode of metasomatism. Li-micas 




associated with leucogranitic cupolas show quite similar textures, with primary mica flakes forming layers, and secondary fine-grained crystals intergrown with quartz forming irregular replacement bodies (e.g. Castillejo de Dos Casas). Less commonly, in these cupolas lepidolite forms white, pearly, subhedral flakes which are intergrown with anhedral quartz crystals in subrounded masses of up to $10 \mathrm{~cm}$ in diameter (e.g. Pinilla de Fermoselle). Li-micas have not been found in the beryl-phosphate subtype pegmatites, nor in the quartz-montebrasite veins.

Micas from the pegmatite fields and from Li mineralization associated with granitic cupolas plot on a similar trend in the Tischendorf diagram (Tischendorf et al., 2004), originating from muscovitic compositions and evolving toward Lirich compositions (Fig. 3). The highest Li contents in micas are those observed in mineralization associated with granitic cupolas (e.g. Castillejo de Dos Casas, Pinilla de Fermoselle), where some of the micas are very close to the polylithionite composition (Table 3, Fig. 3). In contrast, the micas associated with the most fractionated pegmatites in the pegmatite fields do not attain such high Li contents, the micas that are most enriched in $\mathrm{Li}$ being intermediate between trilithionite and polylithionite compositions (Table 3, Fig. 3), (e.g. Fregeneda-Almendra, Las Navas, Gonçalo, Tres Arroyos and Barroso-Alvão fields). In both cases the dominant mechanism of $\mathrm{Li}$ incorporation appears to be the exchange vector $\mathrm{Li}_{3} \mathrm{Al}_{-1} \mathrm{Vac}_{-2}$, and to a lesser extent $\mathrm{Si}_{2} \mathrm{LiAl}_{-3}$ (e.g. Roda-Robles et al., 2006; Vieira et al., 2011, Martins, et al. 2012). In the beryl-phosphate pegmatites the mica composition follows the muscovite-biotite trend, with no $\mathrm{Li}$ (nor $\mathrm{F}$ ) enrichment (Fig. 3).

Iron-lithium-rich micas in $\mathrm{Li}$ mineralization associated with leucogranite cupolas follows an evolutionary trend from biotite through zinnwaldite toward polylithionite (Fig. 3). In these micas, the $\mathrm{Li}$ enrichment is parallel to an Fe decrease, via the AlLiR $_{-2}, \mathrm{SiLi}_{2} \mathrm{R}_{-3}$ and $\mathrm{SiLiAl}_{-1} \mathrm{R}_{-1}$ substitution mechanisms (Roda-Robles et al., 2006). In metasomatized mica-schists hosting the quartz-rich hydrothermal veins at Valdeflores, both Fe-Li-rich and Al-Li-rich metasomatic micas can be distinguished. The Fe-Li-rich micas follow a similar trend to the Fe-Li-rich micas in the leucogranitic cupolas, whereas the Al-Li-micas show an evolution from muscovite towards zinnwaldite, with the $\mathrm{Li}$ enrichment via the substitution $\mathrm{FeLiAl}_{1} \mathrm{Vac}_{-1}$ (Pesquera et al., 1999) (Fig. 3). 


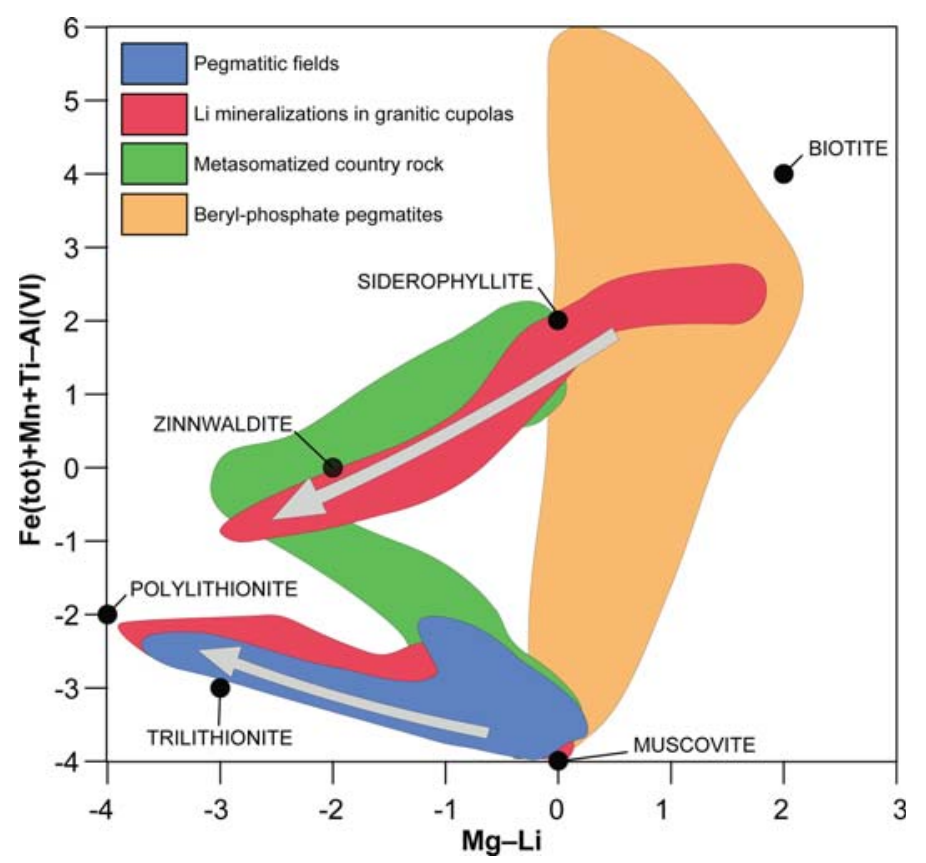

FIG. 3. $\mathrm{Mg}-\mathrm{Li}$ vs. $(\mathrm{Fe}+\mathrm{Mn}+\mathrm{Ti})-{ }^{\mathrm{VI}} \mathrm{Al}$ for the micas associated with the different types of Li mineralization and their metasomatized country rocks.

\section{Lithium aluminosilicates}

The two Li-aluminosilicate mineral phases, spodumene and petalite, are restricted to a few of the aplite-pegmatite dykes occurring in some of the pegmatite fields of the Central Iberian Zone and Galizia-Trás-Os-Montes Zone (Tables 1 and 2). Spodumene is the most common Li-aluminosilicate associated with this type of $\mathrm{Li}$ mineralization (e.g. in the Fregeneda-Almendra, Lalín-Forcarei and Barroso-Alvão pegmatite fields). However, petalite is the dominant aluminosilicate in some pegmatites, both in the pegmatite fields mentioned above, and in some other fields (e.g. Queiriga-Lousadela, Seixoso-Vieiros, Dias et al., 2013). It is also quite common for the two phases to coexist in the same body, showing different mutual relationships explained below (e.g. Fregeneda-Almendra and Barroso-Alvão). The abundance of these minerals in parts of the pegmatite is highly variable, from $<2$ vol. $\%$ up to locally $\sim 50$ vol. $\%$ (Fig. $2 d$ ). In all cases the crystals have highly-variable grain sizes, from very small crystals $(<1 \mathrm{~cm})$ to coarse wedgeshaped crystals up to $20 \mathrm{~cm}$ long. The largest grains are typically randomly distributed within the pegmatite, without any preferred orientation. However, in some cases they are perpendicular to the contacts with the country rock. Petalite and spodumene exhibit similar prismatic or wedgeshaped habits and whitish colours, making it difficult to distinguish between the two in the field. As spodumene is weathered, its cleavage becomes more visible and its colour changes to pale grey. In thin sections several different petrographic varieties of spodumene can be recognized. It appears most commonly as subhedral prismatic crystals, grouped in aggregates, with quartz, mica and plagioclase filling the spaces between the spodumene prisms (Fig. $4 a$ ). It is locally very fresh, but more commonly shows varying amounts of alteration. This alteration usually begins at the margins of the crystals and in some cases the primary crystals are completely pseudomorphed by cookeite and/or clay minerals. Spodumene commonly appears intergrown with tiny blebs of quartz (Fig. $4 b$ ), which probably corresponds to the SQUI texture defined by Černý and Ferguson (1972) and interpreted as the result of the breakdown of petalite into spodumene + quartz. Spodumene and petalite also coexist in some pegmatites with intriguing mutual relationships (some of which have already been described by Charoy et al., 2001 for BarrosoAlvão). These two minerals may form a lamella- 


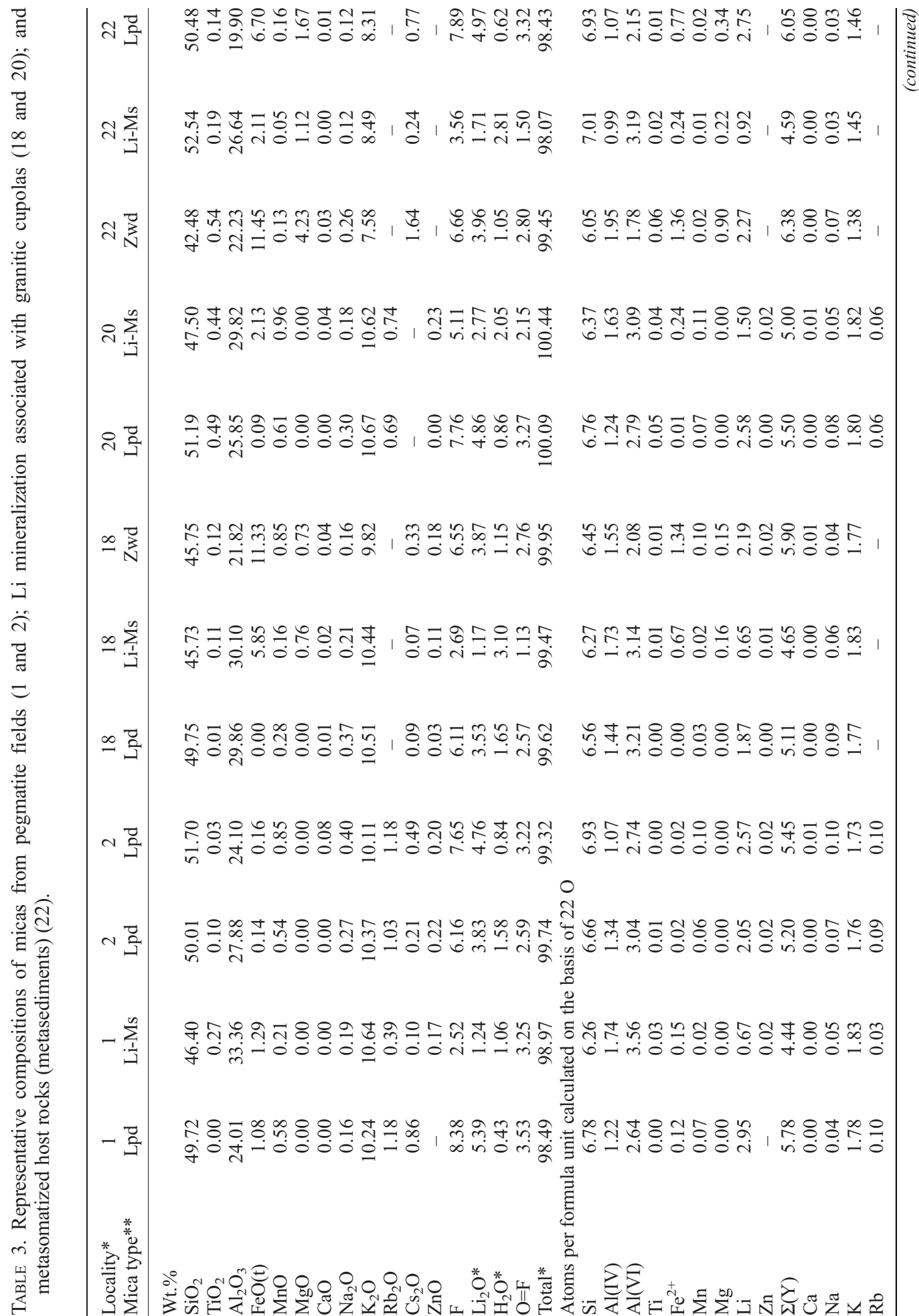




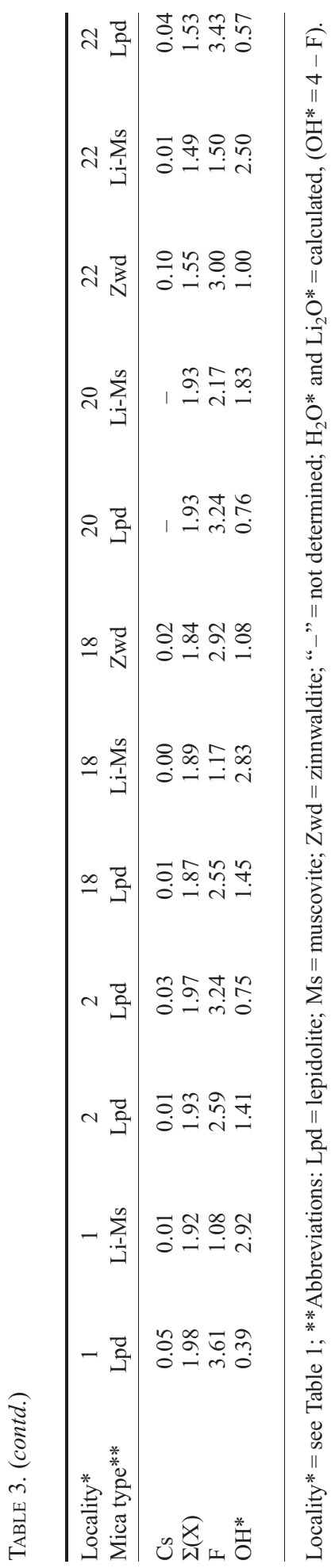

like rhythmic layering, or mantled textures in which spodumene is rimmed by petalite. Petalite also appears interstitially between spodumene prisms (Fig. 4c). In the dykes where petalite is the main Lialuminosilicate it shows different textures. The large wedge-shaped crystals of petalite that can be observed in hand samples appear in thin sections as very fine- to fine-grained aggregates of anhedral crystals (Fig. $4 d$ ). In common with spodumene, petalite may be partly or totally replaced by cookeite and clay minerals, or by eucryptite. Petalite has been also observed as an accessory mineral phase in the stockscheider of Castillejo de Dos Casas, where it forms anhedral fine-grained crystals.

Representative compositions of spodumene, petalite and eucryptite associated with Li mineralization from three localities in the Central Iberian Zone are given in Table 4. In general the composition of these phases is quite similar across the different localities. There is some distinct variation in the Fe content of spodumene, which is typically lower in the dykes where it occurs together with Li-mica $(<0.06$ wt.\%), than in those where micas are absent or scarce (up to $0.41 \mathrm{wt} . \%$ ) (e.g. in the Fregeneda-Almendra field). In the case of eucryptite this difference is more noticeable, with up to 4.62 wt.\% $\mathrm{FeO}$ in the crystals from pegmatites with no Li-micas (e.g. Barroso-Alvão), whereas in the dykes where Li-mica is abundant the $\mathrm{FeO}$ contents in eucryptite are always $<0.36 \mathrm{wt} . \%$.

\section{Amblygonite-montebrasite series}

Lithium aluminophosphates of the amblygonitemontebrasite series represent probably the ubiquitous Li phase of the Li mineralization of the Central Iberian Zone and Galizia-Trás-Os-Montes Zone (Tables 1 and 2). Amblygonite-montebrasite occurs as the main Li-bearing phase in a number of hydrothermal quartz veins, usually located around or inside leucogranitic cupolas (e.g. Valdeflores, Barquilla, Golpejas, Massueime, El Trasquilón). In these veins, it forms whitish irregular masses of up to $30 \mathrm{~cm}$ in diameter, distinguishable from albite by its notably higher density. It is commonly altered and replaced by other secondary phosphates, including lacroixite and turquoise, which gives a characteristic bluish or greenish colour to these phosphate masses (Fig. 2e). Members of the amblygonite-montebrasite series constitute a common accessory phase in many dykes of the pegmatite fields (e.g. Fregeneda-Almendra, Barroso-Alvão, Tres Arroyos). In some of these 



FIG. 4. Photomicrographs of: (a) primary prismatic crystals of spodumene; $(b)$ crystals of spodumene intergrowth with subrounded crystals of quartz, in a SQUI texture (for further explanation see text); $(c)$ interstitial petalite crystals between spodumene prisms; $(d)$ granular anhedral crystals of petalite; $(e)$ montebrasite crystal showing its characteristic polisynthetic twinning; $(f)$ granular ferrisicklerite (reddish) together with some garnet crystals (lower-left corner) and quartz; $(g)$ sarcopside lamellae inside triphylite (greyish matrix); $(h)$ ferrisicklerite (orange) partly-replaced by heterosite (purple) and alluaudite (yellow). ( $a, b, c, d, e$ and $g$ : crossed-polarized light; $f$ and $h$ : plane-polarized light. Scale: $1.8 \mathrm{~mm} \times 2.6 \mathrm{~mm}$ ). Abbreviations: $\mathrm{Spd}=$ spodumene; $\mathrm{Ptl}=$ petalite; $\mathrm{SQUI}=$ spodumene + quartz blebs intergrowth; $\mathrm{Mtb}=$ montebrasite; Allu $=$ alluaudite; $\operatorname{Stan}=$ staneckite; Fsck = ferrisicklerite; $\mathrm{Qtz}=$ quartz; Grt $=$ Garnet; Triph $=$ triphylite; Het $=$ heterosite . 


\section{E. RODA-ROBLES ETAL.}

fields montebrasite may be the only Li-rich phase occurring in some of the less-fractionated pegmatites (e.g. Fregeneda-Almendra, Tres Arroyos). As an accessory phase, amblygonite-montebrasite occurs as whitish, fine-grained crystals. It may be locally very abundant in some of the most Lienriched dykes; for example, at Gonçalo it occurs in masses of up to $12 \mathrm{~cm}$ in diameter. Montebrasite has also been found in some of the beryl-phosphate pegmatites as an accessory mineral, together with other Al phosphates, such as eosphorite-childrenite (e.g. Cañada pegmatite). In these rocks, members of the amblygonite-montebrasite series appear as anhedral to subhedral crystals ranging in size from $<1 \mathrm{~mm}$ to $5 \mathrm{~mm}$, with high order interference colours and commonly showing polysynthetic twinning (Fig. 4e).

Representative compositions of members of the amblygonite-montebrasite series associated with the four types of Li mineralization are listed in Table 5. The F/OH ratios vary between the different hosting lithologies (Fig. 5a). The lowest F contents are found in the montebrasites associated with the beryl-phosphate pegmatites $(0.0-2.18$ wt.\%). Montebrasite in the quartz-montebrasite veins shows minor variations in the $\mathrm{F} / \mathrm{OH}$ ratio, with $\mathrm{F}$ contents in the range $0.94-2.35$ wt.\% (Fig. 5a, Table 5). In contrast, in the Li mineralization associated with leucogranitic cupolas and in pegmatite fields, $\mathrm{F} / \mathrm{OH}$ ratios are rather higher and the $\mathrm{F}$ content of amblygonite-montebrasite ranges from 0.43 to $5.33 \mathrm{wt} . \%$ and from 0.55 to $7.33 \mathrm{wt} \%$, respectively (Fig. $5 a$, Table 5). Nevertheless, the F median values are quite similar for the pegmatite fields, quartz veins and Li mineralization associated with leucogranitic cupolas $(1.84,1.69$ and $1.77 \mathrm{wt} . \%$ respectively), whereas those of the samples from beryl-phosphate pegmatites are clearly lower $(0.68$ wt.\%). In all cases the median and mean values correspond to the F-poor end-member montebrasite.

\section{Triphylite-lithiophilite series}

Members of this series are the most common primary Fe-Mn phosphates associated with pegmatites all over the world. In the Central Iberian Zone they occur mainly associated with the berylphosphate pegmatites, forming dark, sub-rounded masses of up to $1.5 \mathrm{~m}$ in diameter (e.g. Cañada, Nossa Senhora da Assunção, Mangualde). Inside these masses silicate minerals are scarce or absent, quartz and plagioclase being the most common. More rarely, Fe-Mg-(Mn) silicates, such as tourmaline, biotite and/or garnet, appear in close contact with these phosphates, sometimes intimately intergrown with them (Fig. $4 f$ ) (e.g. Cañada pegmatite). In hand samples, fresh triphylitelithiophilite ranges from greyish to beige in colour (Fig. 2f). In thin sections, triphylitelithiophilite minerals are colourless, with very low order interference colours. Triphylite-lithiophilite crystals commonly host lenticular or irregular lamellae of sarcopside that show two preferential crystallographic orientations (e.g. Cañada, Nossa Senhora da Assunção) (Fig. 4g). These lamellae are considered an exsolution product of a higher temperature precursor (Roda-Robles et al., 2011). Triphylite is typically altered following the oxidation sequence described by Quensel (1937) and Mason (1941), with Li leaching and simultaneous progressive oxidation of the transition cations $\mathrm{Fe}^{2+}$ and $\mathrm{Mn}^{2+}$, at a high temperature. The products of this alteration are, in succession, ferrisickleritesicklerite and heterosite-purpurite. In hand samples members of the ferrisicklerite-sicklerite series are dark brown, whereas in thin sections they show strong orange, yellowish and brownish colours (Fig. 4h). Other common replacement products include members of the alluaudite-varulite series, in addition to long list of late-forming secondary phosphates (e.g. Roda et al., 2004).

Iron-manganese phosphates occur only as accessory phases in the pegmatite fields, and in most of the Li mineralization related to granitic cupolas (e.g. Fregeneda-Almendra, Barroso-Alvão, Tres Arroyos, Castillejo de Dos Casas). Members of the triphylite-lithiophilite series are usually absent in these bodies, but their replacement products, typically members of the ferrisicklerite-sicklerite and heterosite-purpurite series, are relatively common, particularly in pegmatites which show intermediate degrees of fractionation. Only in one example of $\mathrm{Li}$ mineralization associated with granitic cupolas, the Pinilla de Fermoselle pegmatite, have volumetrically important amounts of Fe-Mn phosphates been found. In this pegmatite subrounded masses $(<1 \mathrm{~m}$ in diameter) of ferrisicklerite occur in the intermediate zone of the pegmatite. No relict of triphylite has been observed, and ferrisicklerite has been considered here as a primary phase, subsequently replaced by heterosite and/or alluaudite plus a number of later secondary phosphates (Fig. 4h) (Roda et al., 1996).

Representative compositions of Fe-Mn phosphates associated with beryl-phosphate pegmatites, pegmatite dykes from pegmatite fields and $\mathrm{Li}$ mineralization associated with leucogranitic 







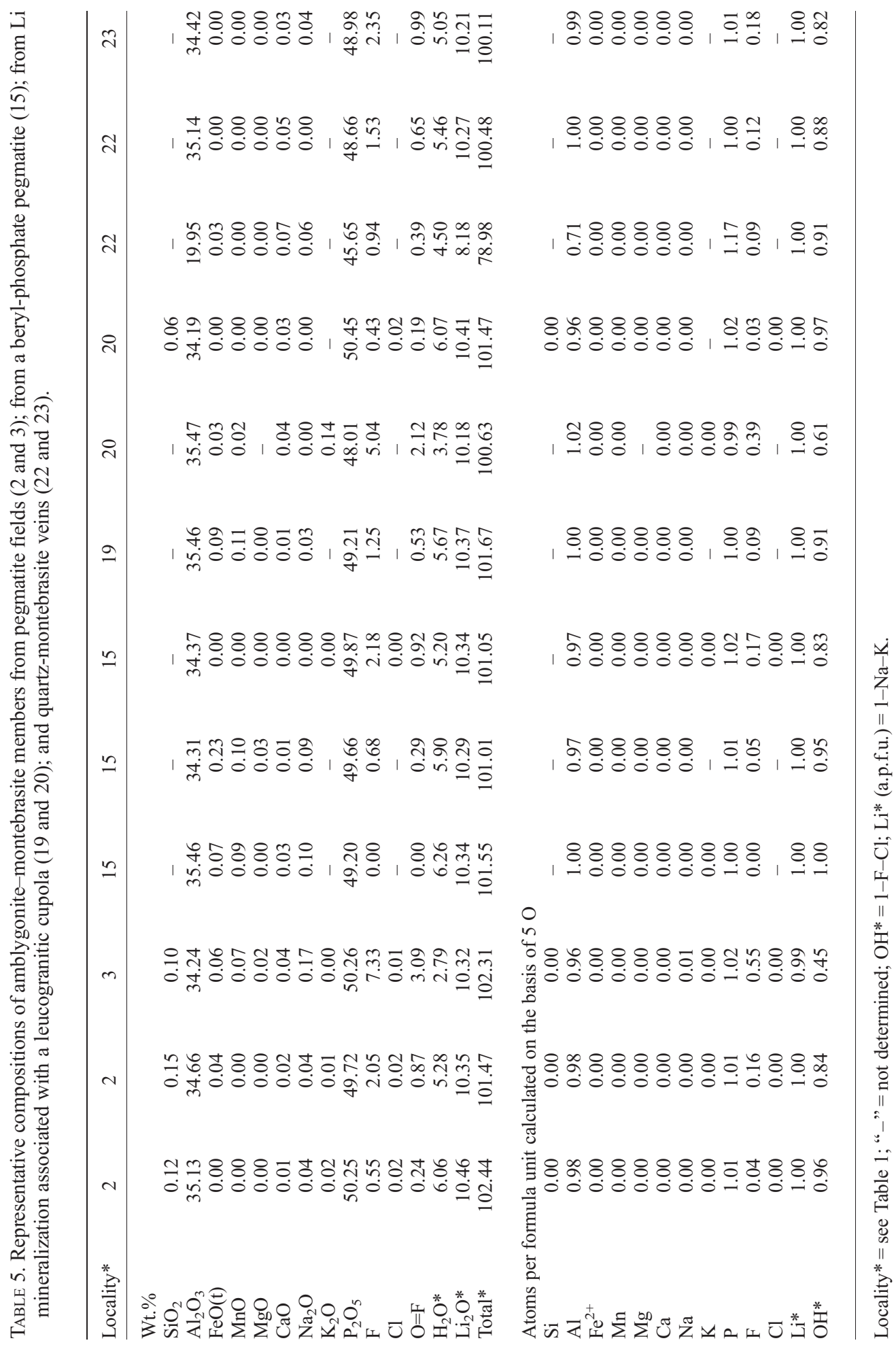



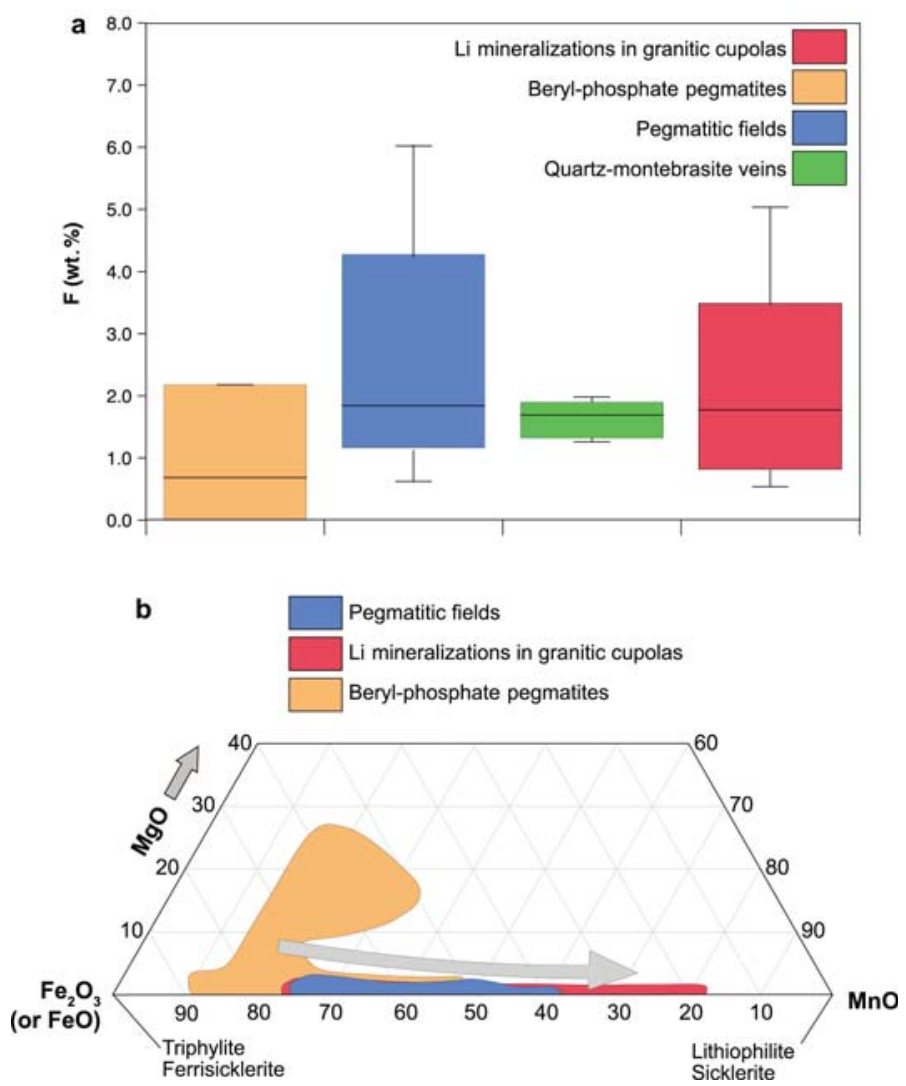

FIG. 5. (a) Variation in the F-content for members of the amblygonite-montebrasite series associated with the different types of $\mathrm{Li}$ mineralization; and $(b)$ ternary plot of the $\mathrm{Fe}_{2} \mathrm{O}_{3}-\mathrm{MnO}-\mathrm{MgO}$ contents for the $\mathrm{Li}-\mathrm{Fe}-\mathrm{Mn}$ phosphates from the different types of Li mineralization.

cupolas are reported in Table 6 and plotted in Fig $5 b$. The highest $\mathrm{Fe}$ and $\mathrm{Mg}$ contents are shown by the triphylite and ferrisicklerite crystals associated with the beryl-phosphate pegmatites ( $\mathrm{FeO}$ from 22.7 to $45.5 \mathrm{wt} . \%$ and $\mathrm{MgO}$ from 0.0 to $11.7 \mathrm{wt} . \%$ ). The Mn contents in the phosphates from the berylphosphate pegmatites are higher than those of $\mathrm{Fe}$ in just a few cases, and always close to the limit between triphylite-lithiophilite and ferrisickleritesicklerite (5.4-24.4 wt.\% MnO) (Fig. 5b). The FeMn phosphates in the pegmatite fields and in the leucogranitic cupolas are in general richer in $\mathrm{Mn}$ and poorer in $\mathrm{Fe}$ and $\mathrm{Mg}$ than those of the berylphosphate pegmatites. The lowest $\mathrm{Mn}$ and highest Fe values are quite similar for both types of mineralization, whereas the highest $\mathrm{Mn}$ and lowest Fe contents are found in the phosphates associated with the Li mineralization in leucogranitic cupolas (13.9-36.6 wt.\% $\mathrm{MnO}$ and 8.47-43.8 wt.\% FeO for the Li mineralization in leucogranitic cupolas; and $11.0-27.8$ wt. $\% \mathrm{MnO}$ and $18.0-36.5$ wt. $\% \mathrm{FeO}$ for the pegmatite fields) (Table 6, Fig. $5 b$ ).

\section{Discussion}

\section{Classification of the Li-rich bodies in the Central Iberian Zone}

On the basis of field relationships, petrographic and mineralogical data, four types of $\mathrm{Li}$ mineralization have been established in the Central Iberian Zone. Three of these types, the pegmatite dykes in pegmatite fields, the beryl-phosphate pegmatites and the apical parts of leucogranitic cupolas, are dominated by granitic pegmatites with different mineralogy, textures, and relationships to host rocks. The fourth type, the quartz-montebrasite veins, are better considered as hydrothermal bodies 


\section{E. RODA-ROBLES ETAL.}

due to the high proportion of quartz and the scarcity of minerals characteristic of granitic pegmatites, such as feldspars and micas. The mineral assemblage and composition of the three pegmatite types are consistent with the rare-element $(R E L)$ class, and $R E L$-Li subclass, according to the classification of Černý and Ercit (2005). The least Li-enriched pegmatites of the three types are usually those enriched in Fe-Mn phosphates and beryl, which may be classified in the beryl-columbite-phosphate subtype of the beryl type (Černý and Ercit, 2005). The most Li-enriched bodies in the Central Iberian Zone are the most fractionated pegmatites in the pegmatite fields and the Li mineralization associated with leucogranitic cupolas. In these two cases the mineralogy and textures are quite similar, with Li-micas dominating in the most evolved Frich facies, whereas spodumene and petalite dominate in those bodies with lower F contents. From the mineralogical point of view, these pegmatites could be assigned to the lepidolite, spodumene or petalite subtype of the complex type (Černý and Ercit, 2005). However, the textures, internal structure and whole-rock compositions of these bodies are quite different to the most typical pegmatites of this type. The Central Iberian Zone and Galizia-Trás-Os-Montes Zone pegmatites commonly have aplitic texture, with strong preferred orientation of wedge-shaped feldspar crystals, and more rarely, spodumene and petalite crystals. The pegmatite bodies range from almost homogeneous to strongly layered, and are highly-enriched in albite. These features are more typical of the albite type than of the complex type pegmatites of the Černý and Ercit, (2005) classification. Therefore, the classification of these pegmatites is not easy using the groups established by these authors, as they share features of more than one type and subtype.

\section{Origin and evolution of the pegmatitic melts in the Central Iberian Zone}

A magmatic origin for granitic pegmatites is currently the most widely accepted hypothesis for the genesis of pegmatitic melts, even if in some regions an anatectic origin is more probable or at least possible. Granitic pegmatites are mainly located in orogenic belts, being the result of the crystallization of melts that are produced in thickened continental crust due to heating generated by mechanical and/or radiogenic decay processes (Tkachev, 2011). Granitic melts with a crustal origin are typically generated after the culmination of an orogeny, related to an extensional regime that lasts for 30 to 60 m.y. (Sylvester, 1998; Thompson, 1999; Bea, 2004). These granites may be the parental magmas of some pegmatites enriched in rare elements (Tkachev, 2011). Granites related to rare-element pegmatites are commonly peraluminous leucogranites. A possible source for these granites is found in peraluminous metasedimentary rocks, including greywackes and shales (e.g. Puziewicz and Johannes, 1988; PatiñoDouce and Johnston, 1991). Such rocks represent a potential source for many of the Variscan granitoids in the western European Variscan belt (e.g. Peucat et al., 1988; Bea et al., 2003; Bea, 2004; Tartèse and Boulvais, 2010), including the Central Iberian Zone and the Galizia-Trás-Os-Montes Zone. Variations in the nature and depth of the fertile zone could explain the variety of granitoids in this region (Bea, 2004), with metasedimentary rocks of the Schist-Metagreywacke Complex representing possible candidates for the source of these granitoids (Bea et al., 1999, 2003). Consequently, such source rocks could also be responsible for the rare-element enrichment in the pegmatites derived from those granites. Effectively, marine shales may be a source for rare alkalis, such as $\mathrm{Li}, \mathrm{Na}, \mathrm{K}, \mathrm{Rb}$ and $\mathrm{Cs}$, and alkaline earths, such as Be, (mainly contained in micas), and fluxing components (F, B and even $\mathrm{P}$ are usually present in black shales) (London, 2008). Further investigation, nevertheless, is necessary to understand the origin of the parental melts, the mechanisms that led to the extremely high concentrations in rare elements and the distribution of the pegmatitic bodies around the parental pluton. Fractionation of granitic melts is the most widely accepted mechanism to explain the composition of rare-element pegmatitic melts. Fractional crystallization is controlled by a number of factors, including the viscosity of magmas, density and size of crystals, concentration of $\mathrm{H}_{2} \mathrm{O}$ and fluxing components, and dynamics/ deformation of the granite-pegmatite system. Gravitational settling is considered an effective fractionation mechanism for basic and ultrabasic magmas, as the differences of density among the crystals and melt are high enough to allow the just formed crystals to settle. However, in granitic magmas the high density of the melt, together with the lighter weight of the crystals, probably mean that this mechanism is not effective for fractionation, at least during the earlier stages, before the residual melt has become enriched in fluxes which may notably reduce its viscosity (Dingwell et al., 
Li MINERALIZATION IN THE CENTRAL IBERIAN ZONE




1996). The distribution of the rare-element pegmatites in the pegmatite fields, often with the Li-Frichest facies occurring farthest from the parental granite, suggests a previous vertical chemical zonation of the melt within the source pluton. For example, in the Fregeneda-Almendra pegmatite field some Li-rich pegmatites lack zoning across the dyke, but show a clear mineralogical and chemical change along the dyke, with a continuous enrichment in $\mathrm{F}$ and $\mathrm{Li}$ northwards. This could be explained by the inheritance of a previous compositional zoning in the melt, before it intruded the fractures where it crystallized. The greater enrichment in $\mathrm{Li}, \mathrm{F}$, and probably also $\mathrm{B}$ and $\mathrm{H}_{2} \mathrm{O}$, would notably reduce the viscosity of the most fractionated melts (Dingwell et al., 1996), and would also lower the liquidus temperature, enhancing the mobility of the melt. A filter-pressing mechanism (Propach, 1976), related to deformation that expels residual melts upwards, would result in a vertical chemical zonation in the magma chamber (Moyen et al., 2003; Bea et al., 2005). If melt were expelled along fractures, the highly fractionated melt in the upper part of the magma chamber would escape first. The exsolution of a fluid phase could also help the extraction of residual melt from mushes (Sisson and Bacon, 1999). Another mechanism that has been proposed to explain fractional crystallization to give a zoning around a pluton is that of differentiation 'en route' to the surface, with the segregation of solids during magma ascent, which would allow enrichment in incompatible elements in the residual melt (Tartèse and Boulvais, 2010). However, this mechanism probably did not have a significant influence on the chemical evolution of the pegmatites from the pegmatite fields described here, as the occurrence of $\mathrm{Li}$ mineralization in the apical parts of leucogranitic cupolas in the Central Iberian Zone, with a clear upwards zoning, indicates that in situ fractionation of the melt was an effective mechanism of melt differentiation. The compositional, mineralogical and textural similarities of the Li mineralization in the pegmatite fields and associated with leucogranitic cupolas indicate that the protoliths and fractionation mechanisms of the parental melts were quite similar for both. However, in the case of the mineralization associated with leucogranitic cupolas, most probably the system remained closed until the last stages of pegmatite crystallization (Roda et al., 2005; Roda-Robles et al., 2012b). The higher Li and F enrichment attained by micas and the lower $\mathrm{Fe} /(\mathrm{Fe}$ $+\mathrm{Mn}$ ) ratios for phosphates from these bodies indicate a higher degree of fractionation. This may be due to loss of some volatile components, including $\mathrm{H}_{2} \mathrm{O}$ and $\mathrm{B}$, from the melts escaping from the parental plutons, during their displacement. Removal of volatile components would have affected fractionation processes, as these fluxing components increase diffusivity and lower the solidus temperature, which enhances fractionation.

The beryl-phosphate pegmatites usually occur inside anatectic granites, frequently with a gradual contact with the host rock. The degree of enrichment in rare elements (e.g. Li, F, B and Sn) for these bodies is much lower than that of the $\mathrm{Li}$ pegmatites from pegmatite fields and from leucogranitic cupolas. The volumetrically significant amounts of phosphates in these bodies may be explained by the behaviour of $\mathrm{P}$ in peraluminousperphosphorous granitic melts, where the activity of $\mathrm{Ca}$ is low and thus there is more $\mathrm{P}_{2} \mathrm{O}_{5}$ than $\mathrm{CaO}$ to form normative apatite. Crystallization of plagioclase could cause a decrease in the $\mathrm{Ca} / \mathrm{P}$ ratio in the melt. The excess of $\mathrm{P}_{2} \mathrm{O}_{5}$ in late differentiates becomes stronger from the point where apatite no longer precipitates, that is, when $P$ first behaves as an incompatible element (Bea et al., 1992). This $\mathrm{P}$ is progressively concentrated in the residual melt until intermediate degrees of pegmatite fractionation, when its concentration in the melt decreases by the formation of phosphates and/or through tetrahedral substitution within the lattice of the feldspars. Generally there is a low content of mafic constituents in peraluminous granitic pegmatites. The large masses of Fe-Mn phosphate in these berylphosphate pegmatites indicate that, in this case, the concentration of Fe and $\mathrm{Mn}$ in the original melt was still moderately important. A scarcity of boron would also favour the crystallization of Fe-Mn phosphates instead of forming Fe-tourmaline (in these dykes, tourmaline is rarely found). Intermediate levels of in situ fractionation of anatectic peraluminous granitic melts represent the most plausible genetic model for these pegmatites (Roda-Robles et al., 2012b).

Finally, the quartz-montebrasite veins were most probably generated from hydrothermal fluids associated with the latest stages of fractionation of parental granitic and/or pegmatitic melts. According to Černý and Ercit, (2005) a high $\mu \mathrm{PFO} 2$ is required for the crystallization of montebrasite. However, the F content in the montebrasite from these quartz dykes is usually low (Table 5, Fig. $5 a$, median $\approx 1.69$ wt. $\%$ F). If the formula proposed by London et al. (2001) to estimate the concentration of $\mathrm{F}$ in melt from the $\mathrm{F}$ content in 
amblygonite-montebrasite at $585^{\circ}$ and $200 \mathrm{MPa}$ $\mathrm{H}_{2} \mathrm{O}$, is applied, the result is 0.44 wt.\% F. This formula was used for calculation in pegmatitic melts, and it may not be appropriate for hydrothermal fluids. The high concentrations of $\mathrm{P}$ required to form montebrasite in these dykes could be explained, as in the case of the beryl-phosphate pegmatites, by the fractionation of $\mathrm{P}$ as an incompatible element from peraluminous-perphosphorous melts. In this case, a scarcity of mafic components in the original melt may have prevented the formation of $\mathrm{Fe}-\mathrm{Mn}$ phosphates, allowing $\mathrm{P}$ to become enriched in the most fractionated melt.

\section{Lithium exploration clues for the Central Iberian Zone}

The most significant potential for Li mineralization in this region, with inferred economic interest, is associated with the pegmatite fields. In general, the pegmatite bodies with $\mathrm{Li}$ mineralization in the Central Iberian Zone are relatively small, which makes exploration and extraction more attractive in highly populated areas where a small, relatively short-lived open pit operation might have a lower impact on surrounding communities. At the same time, more than one Li-enriched body is usually present in an area with Li enrichment. Thus, various small operations could potentially bring more benefits and development into economically depressed areas of both Portugal and Spain.

As the pegmatite fields include pegmatites with varying degrees of $\mathrm{Li}$ enrichment, it is important to consider some common features for all the pegmatite dykes (barren and $\mathrm{Li}$ rich) that may help in the exploration of Li-enriched pegmatite fields: (1) An aplitic character, with high albite content. Plagioclase may be very white and in thin section it commonly forms myrmekitic intergrowths. (2) The presence of wedge-shaped Kfeldspar crystals, growing perpendicular to the contacts with the host rocks. Some K-feldspar crystals show greyish colours in hand specimen. In thin sections perthitic textures are usually absent or poorly developed. (3) Graphic quartz-feldspar intergrowths are usually absent. (4) Amblygonitemontebrasite and Fe-Mn phosphates are typical accessory minerals, even in the less-evolved pegmatites of those fields. (5) There are low mica proportions, unless the dyke is Li-mica rich. (6) Pinkish, greenish or, more rarely, bluish soapy masses of cookeite or clay minerals, up to $12 \mathrm{~cm}$ long, replacing petalite or spodumene crystals, are key features of some Li-rich pegmatites.

\section{Final remarks}

On the basis of field observations, and of the mineralogical, textural and compositional characteristics of the different types of Li mineralization found in the Central Iberian Zone, the following conclusions can be drawn:

(1) Li mineralization in the Central Iberian Zone may be classified in four types: aplite-pegmatite dykes usually grouped in pegmatite fields, $\mathrm{Li}$ mineralization associated with leucogranitic cupolas, beryl-phosphate pegmatites and quartzmontebrasite veins.

(2) The main Li minerals of these mineralization types include Li-mica, spodumene and/or petalite in the pegmatite fields and leucogranitic cupolas, triphylite-lithiophilite in the beryl-phosphate pegmatites and amblygonite-montebrasite in the quartz-montebrasite veins.

(3) The origin of the Li-mineralization in this region is probably related to the fractional crystallization of peraluminous melts generated by partial melting of metasedimentary rocks in the middle crust during the Variscan orogeny.

(4) The most fractionated pegmatitic bodies are those occurring in the leucogranitic cupolas and, to a lesser extent, in the pegmatite fields. The berylphosphate pegmatites show intermediate degrees of fractionation. The quartz-montebrasite veins are attributed to a later hydrothermal stage.

(5) The highest economic potential for $\mathrm{Li}$ is attained by the pegmatite fields, due to the notable $\mathrm{Li}$ enrichment shown by some of the dykes and the number of mineralized bodies in each field.

(6) Aspects of texture and mineralogy provide indicators that can be used for Li exploration in the Central Iberian Zone.

\section{Acknowledgements}

The authors thank Mercedes Fuertes-Fuente, an anonymous reviewer and the Principal Editor Roger Mitchell, for thorough reviews and comments that have helped to improve the manuscript. Kathryn Goodenough is thanked for copy-editing the text. The authors are indebted to the mining company IMERYS, which has always facilitated access to their quarries and has provided drilling samples for study. FELMICA mining company has also allowed access in some Portuguese open pits. This research has been supported financially by the Spanish Ministerio de Economía y Competitividad (Project CGL201231356, with ERDF funds). Also the University of the Basque Country UPV/EHU contributed economically with the grant GIU/1216. 


\section{E. RODA-ROBLES ETAL.}

\section{References}

Antunes, I.M.H.R., Neiva, A.M.R., Ramos, J.M.F., Silva, P.B., Silva, M.M.V.G. and Corfu, F. (2013) Petrogenetic links between lepidolite-subtype aplitepegmatite, aplite veins and associated granites at Segura (central Portugal). Chemie der Erde Geochemistry, 73, 323-341.

Arenas, R., Martínez Catalán, J.R. and Díaz García, F. (2004) Zona de Galicia Trás Os Montes, introducción. Pp. 133-135 in: Geología de España (J.A. Vera, editor). Sociedad Geológica de España, Instituto Geológico y Minero de España, Madrid.

Azor, A., González Lodeiro, F. and Simancas, J.F. (1994) Tectonic evolution of the boundary between the Central Iberian and Ossa-Morena zones (Variscan belt, southwest Spain). Tectonics, 13, 45-61.

Bea, F. (2004) La naturaleza del magmatismo de la Zona Centro Ibérica: consideraciones generales y ensayo de correlación. Pp. 128-133 in: Geología de España (J.A. Vera, editor). Sociedad Geológica de España, Instituto Geológico y Minero de España, Madrid.

Bea, F., Fershtater, G.B. and Corretgé, L.G. (1992) The geochemistry of phosphorus in granite rocks and the effect of aluminium. Lithos, 29, 43-56.

Bea, F., Montero, P. and Molina, J.F. (1999) Mafic precursors, peraluminous granitoids, and late lamprophyres in the Avila batholith: A model for the generation of Variscan batholiths in Iberia. Journal of Geology, 107, 399-419.

Bea, F., Montero, P. and Zinger, T. (2003) The nature, origin, and thermal influence of the granite source layer of Central Iberia. Journal of Geology, 111, 579-595.

Bea, F., Fershtater, G.B., Montero, P., Smirnov, V.N. and Molina, J.F. (2005) Deformation-driven differentiation of granitic magma: the Stepninsk pluton of the Uralides, Russia. Lithos, 81, 209-233.

Carvalho, J.M.F. and Farinha, J.A.L.B. (2004) Lithium potentialities in Northern Portugal. 17th Industrial Minerals International Congress, Barcelona, Spain, pp. $1-10$.

Černý, P. and Ercit, T.S. (2005) The classification of granitic pegmatites revisited. The Canadian Mineralogist, 43, 2005-2026.

Černý, P. and Ferguson, R.B. (1972) The Tanco pegmatite at Bernic Lake, Manitoba; IV, Petalite and spodumene relations. The Canadian Mineralogist, 11, 660-678.

Charoy, B. and Noronha, F. (1996) Multistage growth of a rare-element, volatile-rich microgranite at Argemela (Portugal). Journal of Petrology, 37, 73-94.

Charoy, B., Noronha, F. and Lima, A. (2001) Spodumene - petalite - eucryptite: Mutual relationships and pattern of alteration in li-rich aplite-pegmatite dykes from Northern Portugal. The Canadian Mineralogist, 39, 729-746.
Christmann, P., Gloaguen, E., Labbé, J.-F., Melleton, J. and Piantone, P. (2015) Global lithium resources and sustainability issues. Pp. 1-40 in: Lithium Process Chemistry. Resources, Extraction, Batteries, and Recycling (A. Chagnes and J. Swiatowska, editors). Elsevier, 40 pp.

Dias, P.A., Pereira, B., Azavedo, J., Oliveira, J., Leal Gomes, C. and Carvalho, J. (2013) Pegmatite productive terrains in the variscan granite hosts from northern and central portugal. 23rd International Mining Congress \& Exhibition of Turkey, Pp. 2121-2129.

Díez Balda, M.A., Vegas, R. and González Lodeiro, F. (1990) Structure of the Central Iberian Zone. Autochthonous Sequences. Structure. Pp. 172-188 in Pre-Mesozoic Geology of Iberia (R.D. Dallmeyer and E. Martínez García, editor). Springer-Verlag, Berlin.

Dingwell, D.B., Hess, K.U. and Knoche, R. (1996) Granite and granitic pegmatite melts: Volumes and viscosities. Transactions of The Royal Society of Edinburgh - Earth Sciences, 87, 65-72.

Farias, P., Gallastegui, G., González Lodeiro, F., Marquínez, J., Martín-Parra, L.M., Martínez Catalán, J.R., de Pablo Maciá, J.G. and Rodríguez-Fernández, L.R. (1987) Aportaciones al conocimiento de la litoestratigrafia y estructura de Galicia central. Memórias da Faculdae de Ciências, Universidade do Porto, 1, 411-431.

Fuertes-Fuente, M. and Martín-Izard, A. (1998) The Forcarei Sur rare-element granitic pegmatite field and associated mineralization, Galicia, Spain. The Canadian Mineralogist, 36, 303-325.

Gallego Garrido, M. (1992) Las mineralizaciones de Li asociadas a magmatismo ácido en Extremadura y su encuadre en la Zona Centro-Ibérica. Tesis Doctoral, Universidad Complutense de Madrid, Spain.

Garate-Olave, I., Roda-Robles, E., Gil-Crespo, P.P. and Pesquera, A. (2014) Caracterización petrográfica y geoquímica de las micas asociadas al sistema granitopegmatitas del área de Tres Arroyos (Alburquerque, Badajoz). Macla, 19.

Garção, J.C.S. (1927) Minas de Lítio e estanho. Pp. 25-31 in: Boletim de Minas. Imprensa Nacional, Lisbon.

Julivert, M., Fontboté, J.M., Ribero, A. and NabaisConde, L.E. (1972) Mapa tectónico de la Península Ibérica y Baleares scale 1:1.000.000. Memoria explicativa. Instituto geológico y Minero de España, Spain, pp. 113.

Leal Gomes, C. (1994) Estudo estructural e paragenético de um sistema pegmatóide granítico. O campo aplitopegmatitico de Arga Minho, Portugal. PhD thesis, Universidade do Minho, Portugal.

Leal Gomes, C., Azevedo, A., Lopes Nunes, J. and Dias, P.A. (2009) Phosphate fractionation in pegmatites of Pedra da Moura II claim - Ponte da Barca - Portugal. Estudos Geológicos, 19, 172-176. 
Lima, A. (2000) Estrutura, Mineralogia e Génese dos Filões Aplitopegmatíticos com Espodumena da Região do Barroso-Alvão (Norte de Portugal). Univ. Porto, Portugal and INPL, Nancy, France, 270 pp.

Lima, A., Rodrigues, R., Guedes, A. and Novák, M. (2009) The rare elements-rich granite of Seixoso Area (Outeiro Mine). Preliminary results. Estudos Geológicos, 19, 182-187.

London, D. (2008) Pegmatites. The Canadian Mineralogist, Special Publication, 10, pp. 347.

London, D., Evensen, J.M., Fritz, E., Icenhower, J.P., Morgan VI, G.B. and Wolf, M.B. (2001) Enrichment and accomodation of manganese in granite-pegmatite systems. Geochimica Et Cosmochimica Acta, Eleventh Annual V. M. Goldschmidt Conference, May 20-24, 2001, Hot Springs, Virginia. Abstract n 3369.

Martín-Izard, A., Reguilón, R. and Palero, F. (1992) Las mineralizaciones litiníferas del oeste de Salamanca y Zamora. Estudios Geológicos, 48, 9-13.

Martínez Catalán, J.R. (1985) Estratigrafia y estructura del Domo de Lugo : (Sector Oeste de la Zona Asturoccidental-leonesa). 324 pp. Fundacion Coruña "Pedro Barrié de la Maza,Conde Fenosa" La Coruña.

Martínez Catalán, J.R., Arenas, R., Díaz García, F., Rubio Pascual, F.J., Abati, J. and Marquínez, J. (1996) Variscan exhumation of a subducted paleozoic continental margin: The basal units of the Ordenes Complex, Galicia, NW Spain. Tectonics, 15, 106-121.

Martínez Catalán, J.R., Martínez Poyatos, D. and Bea, F. (2004) Zona Centroibérica: Introducción. Pp. 68-69 in: Geología de España (J.A. Vera, editor). Sociedad Geológica de España, Instituto Geológico y Minero de España, Madrid.

Martínez-Fernández, F.J. (1974) Estudio del área metamórfica y granítica de los Arribes del Duero (Prov. de Salamanca y Zamora). PhD Thesis, Univ. de Salamanca, Spain.

Martínez, F.J., Julivert, M., Sebastián, A., Arboleda, M.L. and Gil-Ibarguchi, J.I. (1988) Structural and thermal evolution of high-grade areas in the northwestern parts of the Iberian Massif. American Journal of Science, 288, 969-996.

Martins, T., Roda-Robles, E., Lima, A. and de Parseval, P. (2012) Geochemistry and Evolution of Micas in the Barroso-Alvao Pegmatite Field, Northern Portugal. The Canadian Mineralogist, 50, 1117-1129.

Mason, B. (1941) Minerals of the Varuträsk pegmatite. XXIII. Some iron-manganese phosphate minerals and their alteration products, with special reference to material from Varuträsk. Geolpgoske Föreniugen $i$ Stockholm Förhandlgar, 63, 25-34.

Moyen, J.-F., Martin, H., Jayananda, M. and Auvray, B. (2003) Late Archaean granites: a typology based on the Dharwar Craton (India). Precambrian Research, 127, 103-123.
Neiva, A.M.R. and Ramos, J.M.F. (2010) Geochemistry of granitic aplite-pegmatite sills and petrogenetic links with granites, Guarda-Belmonte area, central Portugal. European Journal of Mineralogy, 22, 837-854.

Neiva, A.M.R., Ramos, J.M.F. and Silva, P.B. (2011) Alguns aplito-pegmatitos graníticos com minerais de Li das regiões centro e norte de Portugal. Pp. 23-26 in: Valorização de Pegmatitos Litiníferos (L.M.P. Martins, D.P.S. de Oliveira, R. Silva, H.M.C. Viegas and R.C. Vilas Bôas, editors). Lisbon, Portugal.

Noronha, F., Ramos, J.M.F., Rebelo, J., Ribeiro, A. and Ribeiro, M.L. (1981) Essai de corrélation des phases de déformation hercyniennes dans le nord-ouest Péninsulaire. Leidse Geologische Mededelingen, 52 (1), 87-91.

Patiño Douce, A.E. and Johnston, A.D. (1991) Phase equilibria and melt productivity in the pelitic system: implications for the origin of peraluminous granitoids and aluminous granulites. Contributions to Mineralogy and Petrology, 107, 202-218.

Pérez-Estaún, A., Bea, F., Bastida, F., Marcos, A., Martínez Catalán, J.R., Martínez Poyatos, D., Arenas, R., Díaz García, F., Azor, A., Simancas, J.F. and González Lodeiro, F. (2004) La Cordillera Varisca europea: El Macizo Ibérico. Pp. 21-25 in: Geología de España (J.A. Vera, editor). Sociedad Geológica de España, Instituto Geológico y Minero de España, Madrid.

Pesquera, A., Torres Ruiz, J., Gil-Crespo, P.P. and Velilla, N. (1999) Chemistry and genetic implications of tourmaline and Li-F-Cs micas from the Valdeflores area (Cáceres, Spain). American Mineralogist, 84, 55-69.

Peucat, J.J., Jegouzo, P., Vidal, P. and Bernard-Griffiths, J. (1988) Continental crust formation seen through the $\mathrm{Sr}$ and $\mathrm{Nd}$ isotope systematics of S-type granites in the Hercynian belt of western France. Earth and Planetary Science Letters, 88, 60-68.

Pouchou, J.L. and Pichoir, F. (1985) "PAP" $\varphi(\mathrm{pz})$ procedure for improved quantitative microanalysis. Pp. 104-106 in: Microbeam Analysis. San Francisco Press, San Fransisco, USA.

Propach, G. (1976) Models of filter differentiation. Lithos, 9, 203-209.

Puziewicz, J. and Johannes, W. (1988) Phase equilibria and compositions of Fe-Mg-Al minerals and melts in watersaturated peraluminous granitic systems. Contributions to Mineralogy and Petrology, 100, 156-168.

Quensel, P. (1937) Minerals of the Varuträsk pegmatite. I: The lithium-manganese phosphates. Geologiska Föreningeni Stockholm Förhandlingar, 59, 77-96.

Roda, E., Fontan, F., Pesquera, A. and Velasco, F. (1996) The phosphate mineral association of the granitic pegmatites of the Fregeneda area (Salamanca, Spain). Mineralogical Magazine, 60, 767-778.

Roda, E., Pesquera, A., Velasco, F. and Fontan, F. (1999) The granitic pegmatites of the Fregeneda area 


\section{E. RODA-ROBLES ETAL.}

(Salamanca, Spain): characteristics and petrogenesis. Mineralogical Magazine, 63, 535-558.

Roda, E., Pesquera, A., Fontan, F. and Keller, P. (2004) Phosphate mineral associations in the Canada pegmatite (Salamanca, Spain): Paragenetic relationships, chemical compositions, and implications for pegmatite evolution. American Mineralogist, 89, $110-125$.

Roda, E., Pesquera, A., Gil-Crespo, P.P., Torres-Ruiz, J. and Fontan, F. (2005) Origin and internal evolution of the Li-F-Be-B-P-bearing Pinilla de Fermoselle pegmatite (Central Iberian Zone, Zamora, Spain). American Mineralogist, 90, 1887-1899.

Roda-Robles, E., Pesquera, A., Gil-Crespo, P.P., TorresRuiz, J. and De Parseval, P. (2006) Mineralogy and geochemistry of micas from the Pinilla de Fermoselle pegmatite (Zamora, Spain). European Journal of Mineralogy, 18, 369-377.

Roda-Robles, E., Mateus, S., Vieira, R., Martins, T., Vide, R. and Lima, A. (2008) Phosphate mineral associations in the Seixeira pegmatite (Bendada, Sabugal, Guarda, Portugal): preliminary results. IX CGPLPIX Congresso de Geoquímica dos Países de Língua Portuguesa, Abstracts, p. 39.

Roda-Robles, E., Vieira, R., Lima, A. and Pesquera-Pérez, A. (2009) Petrogenetic links between granites and pegmatites in the Fregeneda-Almendra area (Salamanca, Spain and Guarda, Portugal): new insights from ${ }^{40} \mathrm{Ar} /{ }^{39} \mathrm{Ar}$ dating in micas. Estudos Geológicos, 19, 305-310.

Roda-Robles, E., Galliski, M., Nizamoff, J., Simmons, W., Keller, P., Falster, A. and Hatert, F. (2011) Cation partitioning between minerals of the triphylite \pm graftonite \pm sarcopside association in granitic pegmatites. Contributions to the 5th International Symposium on Granitic Pegmatites, pp. 161-164, Mendoza (Argentina).

Roda-Robles, E., Pesquera, A., Gil-Crespo, P.P. and Torres-Ruiz, J. (2012a) The Puentemocha berylphosphate granitic pegmatite, Salamanca, Spain: Internal structure, petrography and mineralogy. The Canadian Mineralogist, 50, 1573-1587.

Roda-Robles, E., Pesquera, A., Gil-Crespo, P.P. and Torres-Ruiz, J. (2012b) From granite to highly evolved pegmatite: A case study of the Pinilla de Fermoselle granite-pegmatite system (Zamora, Spain). Lithos, 153, 192-207.

Roda-Robles, E., Pesquera, A., Gil-Crespo, P.P., GarateOlave, I. and Ostaikoetxea-Garcia, U. (2013) Textural and mineralogical features of the Li-F-Sn-bearing pegmatitic rocks from Castillejo de Dos Casas (Salamanca, Spain): preliminary results. 6th International Symposium On Granitic Pegmatites, pp. 118-119.

Roda-Robles, E., Pesquera, A., Lima, A., Vieira, R. and GilCrespo, P.P. (2012c) Origin and significance of phosphate minerals in the Central Iberian Zone (Spain and Portugal): implications for the behaviour of $\mathrm{P}$ during the Variscan magmatism. European Mineralogical Conference EMC2012, 1, p. 381.

Roda-Robles, E., Pesquera, A., de Madinabeitia, S.G., Ibarguchi, J.I.G., Nizamoff, J., Simmons, W., Falster, A. and Galliski, M.A. (2014) On the geochemical character of primary Fe-Mn phosphates belonging to the triphylite-lithiophilite, graftonite-beusite, and triplite-zwieselite series: First results and implications for pegmatite petrogenesis. The Canadian Mineralogist, 52, 321-335.

Roda-Robles, E., Pesquera, A., Gil-Crespo, Garate-Olave, I., P.P. and Torres-Ruiz (2015) The Li-rich aplopegmatite from Castillejo de Dos Casas (Salamanca, Spain): Example of a highly fractionated granite-pegmatite system. Proceedings SGA2015, vol. $2,11-15$.

Sisson, T.W. and Bacon, C.R. (1999) Gas-driven filter pressing in magmas. Geology, 27, 613-616.

Sylvester, P.J. (1998) Post-collisional strongly peraluminous granites. Lithos, 45, 29-44.

Tartèse, R. and Boulvais, P. (2010) Differentiation of peraluminous leucogranites "en route" to the surface. Lithos, 114, 353-368.

Thompson, A.B. (1999) Some time-space relationships for crustal melting and granitic intrusion at various depths. Geological Society, London, Special Publications, 168, 7-25.

Tischendorf, G., Rieder, M., Forster, H.J., Gottesmann, B. and Guidotti, C.V. (2004) A new graphical presentation and subdivision of potassium micas. Mineralogical Magazine, 68, 649-667.

Tkachev, A.V. (2011) Evolution of metallogeny of granitic pegmatites associated with orogens throughout geological time. Geological Society, London, Special Publications, 350, 7-23.

Vieira, R., Roda-Robles, E., Pesquera, A. and Lima, A. (2011) Chemical variation and significance of micas from the Fregeneda-Almendra pegmatitic field (Central-Iberian Zone, Spain and Portugal). American Mineralogist, 96, 637-645. 